\title{
Differentials in Metropolitanisation Trends in Lagos Peri-Urban Settlements
}

\author{
Funmilayo Mokunfayo Adedire ${ }^{1}$ \\ ${ }^{1}$ Department of Architecture, University of Lagos, Akoka, Lagos State, Nigeria \\ Correspondence: Funmilayo Mokunfayo Adedire, Department of Architecture, University of Lagos, Akoka, \\ Lagos State, Nigeria. E-mail: funmidire@gmail.com
}

Received: September 4, 2017

Accepted: September 22, 2017 Online Published: October 23, 2017

doi:10.5539/jsd.v10n6p14

URL: https://doi.org/10.5539/jsd.v10n6p14

\begin{abstract}
This paper examines the differential in the metropolitanisation of Lagos peri-urban settlements and the policy implication on locational quality of the emerging settlements. Two case studies of Ibeju-Lekki and Ikorodu were selected to represent the peri-urban settlements outside Lagos metropolitan regions. Using purposive sampling, thirty four settlements were selected which comprise sixteen and eighteen in Ibeju-Lekki and Ikorodu respectively. Data was sourced primarily through administration of 370 and 384 questionnaires to household heads in the selected settlements in Ibeju-Lekki and Ikorodu. Secondary data was sourced by conversion of analogue spatial images, the land use maps and satellite images of the study area to digital format. Spatial images from 1980 through 2016 were acquired for this study. Acquired satellite images from Google Earth archive were brought into ArcGIS environment for geo-referencing. Quantitative data was analysed using descriptive statistics while qualitative data was analysed using time series and satellite image analysis. Findings show a differential in transformation of the two cases due to varying demographic characteristics of residents, the locational convenience, level of linkages and the regional government housing policy. It is recommended that the regional planning should create a balance between the pace of development and infrastructural provision in the peri-urban to limit the disparity in development in Lagos peri-urban settlements.
\end{abstract}

Keywords: commuting, housing, land use, linkages, peri-urban, socio-demography

\section{Introduction}

There is an evidential differential in the extent and causes of metropolitanisation of Lagos peri-urban due to many factors which include government policy on land use, accessibility to services, linkages to the metropolitan region, the socio-demography and finally availability and affordability of housing for the low income migrants. The gradual conversion of land at the peripheral of cities if well managed can bring about benefits in the area of provision of housing for urban population and space for industrial expansion that cannot be accommodated in the saturated city core (Wu \& Zhang, 2013). Most often the pattern and rate of land conversion from agricultural land use to residential land use at the fringe is not matched with corresponding infrastructure thus posing several challenges to planning and creating a distortion of urban policy (Allen, 2003). Capturing the emerging development primarily not provided for in the conventional planning is a herculean task for the city managers because of the dispersed nature of peri-urban settlements.

Metropolitanisation of urban fringes in Lagos state is facilitated by many actors often with conflicting interest as seen in other developing countries (Lawanson, Yadua, \& Salako, 2012). Complex interactions of forces determine the extent of sustainability of the peripheral settlements. Also the multi-cultural mix of the population makes it difficult for integration of effective community participation in supply of services not provided by municipal authority (Allen, 2010). The socio-demography of the migrants determines the quality and success of participative planning and development. A positively and economically induced urbanisation in the peri-urban involves regional government participation in building corporate infrastructure to service the emerging settlements in the peri-urban interface (Allen, da Silva, \& Corubolo, 1999).

Government disparity in infrastructure development is a major cause of the differential in the metropolitanisation of peri-urban in developing nations. And also the lack of compactness of settlements in some peri-urban, pose a huge economic burden in terms of building efficient services (Browder, Bohland, \& Scarpaci, 1995). Scattered peri-urban suffer from lack of infrastructure due to dispersed nature. Hence the morphology of a peri-urban 
settlement is vital in determining the extent of expansion. The place of effective linkages through different means of transportation cannot be underemphasized in the development of metropolitan suburbia. Settlements cannot expand beyond the existing linkages. Ease of commuting encourages rapid expansion of the city fringes (Lawanson, Yadua, \& Salako, 2012).

Though few research works have been carried out on land use conversion in Lagos peri-urban, the underlying causes of the differentials in extent and pattern of development is yet to be investigated. Notable investigation were on rural-urban linkages, environmental quality and livelihoods in Nigerian peri-urban settlements (Bah, Diyamett, Lerise, Okali \&Tacoli, 2003; Binns, Maconachie, \& Tanko, 2003; Nwokoro \& Dekolo, 2012; Lawanson, Yadua, \& Salako, 2012). Therefore, this study seeks to examine the differentials in metropolitanisation of Lagos peri-urban settlements by specifically assessing the causes, extent, actors and policy implication of the peri-urbanisation process in Lagos metropolitan peripheral.

\section{Literature Review}

With high population growth rate and continuous rural-urban drift in most developing countries, housing deficit becomes a critical challenge (McGranaham \& Satterthwaite, 2014). Urbanisation finds expression in outward expansion of built up area and conversion of agricultural lands into residential and industrial uses (Satterthwaite, 2014). According to the National Population Commission (1991) census, $32 \%$ of the Nigerian population lived in urban areas. Urban population increased to $40 \%$ and $48.2 \%$ in 1996 and 2005 respectively thus bringing about demographic and spatial expansion in Lagos State (Aluko, 2010). Therefore to serve the projected 20.19 million urban population, an estimate of 2.55 million new homes is required for the next 5 years to meet housing needs in Lagos State (LASG Economic Intelligence Unit, 2012).

Therefore, urbanisation in Lagos State, Nigeria has attached to it metropolitanisation which is an urban driven transitions in the territory outside the metropolitan regions or urban core. The peri-urban expansion is part of a wider urbanisation process, it is the consequence of urbanisation (Allen, da Silva, \& Corubolo, 1999). It is established by the gradual transformation of rural nature to urban by physical and human interactions. The peri-urban is the newly urbanised zones at the fringe of cities in developing countries (Adell, 1999). Spatial types of rural -urban region are the urban core, urban inner area, the suburban area, urban periphery, rural hinterland (PLUREL, 2009). Further distinguishing factors between rural, peri-urban and urban are population, built up density, infrastructure, administration, boundaries and economies (Ravetz, Fertner, \& Nielsen, 2013).

Due to rapid growth, peri-urban is usually subjected to diverse transformations among which are socio-demographic, morphological, cultural, economic and functional changes (Dutta, 2012). In most developing countries, the urban periphery among many functions allows multi-dimensional development. It provides land for industrial activities that could not be located in the city centre due to the limited land area and also provide a means of housing for the urban population (McGregor, Simon, \& Kwasi, 2004). Peri-urban settlements are emerging as a major provider of housing for the multi-cultural mix of urban population in highly populated cities in developing countries (Browder, Bohland, \& Scarpaci, 1995; Simon, McGregor, \& Nsiah-Gyabaah, 2004; Acheampong \& Anokye, 2013).

The metropolitanisation process occurs in five stages. Firstly is a manifestation of urban expansion as a direct result of growth in population, economic and space demand. Secondly, formation of regional agglomeration with step changes in economies of scale resulting in peri-urban territory. Development of various political and cultural forces then shapes the peri-urban territory. This is followed by a rapid transition and restructuring of the urban system and policy responses to transition and urban changes (Ravetz, Fertner, \& Nielsen, 2013). Ideally, there are overlap and interconnectivity among the stages. These five stages noted above are applicable to peri-urbanisation process in Lagos.

The major drivers of peri-urban development are population, housing, services, infrastructure, economy and employment. Drivers of housing expansion are perceived infrastructural development, presence of improved socio-economic activities and development of the tourism sector (Thapa \& Murayama, 2010). Other identified drivers of peri-urban housing development are rising household incomes and transportation improvement (Dutta, 2012). Also influencing residential growth in the peri-urban are decline of urban environmental quality. Easy access of land for housing development is the major pull factor for potential residential developers for acquisition of land for building and commercial purposes (Appiah, Bugri, Forkuo, \& Boateng, 2014). Also the spread of basic amenities like schools, clinics and potable water contributes to peri-urban housing development.

Transport and communications are key factors in addition to infrastructure in facilitating and encouraging urban-rural migration regarded as counter urbanisation (Bah, et al., 2003; Rozmi, Mohammed, \& Rahim, 2013). Improved transport infrastructure has aided the spread of most peri-urban radially in all directions. Economic 
growth contributes to peri-urban growth due to a relocation of economic activity to peri-urban zones aided by access to large land and major roads. The pull factors for peri-urban growth may be an opportunity to engage in small industry, better living condition, and cheaper land for housing, property investment for the future, improved infrastructure and services and closeness to places of work made achievable by improved transportation and the presence of public and private institutions, also universities (Pradoto, 2012).

The seized opportunities in real estate development in creating well planned towns are another motivating factor for peri-urban expansion. Residents from central districts are moving to the peri-urban for improved housing quality thus creating an increase in the housing market growth in the peripheral (Pow, 2009). Housing in the peri-urban is also seen as means of capital investment because of the threshold of entry that is relatively low. Location of housing in the peri-urban is determined by transport, accessibility to employment and services. This is partially responsible for the growth of peri-urban in Lagos. The peri-urban is emerging with massive investment in housing development and infrastructure development. Lower houses price, large living space and a better environment can be achieved. In Nigeria, drivers of peri-urban housing growth constitute among many, affordable rent in comparison to city and big towns (Lawanson, Yadua, \& Salako, 2012).

Notable actors are peri-urban farmers, peri-urban residents, entrepreneurs, property developers and government institutions (Salem, 2015). Entrepreneur represent the demand side of the land market. They require space for commercial and industrial activities. Property developers control the supply and demand of land market, they have a greater hold on monetary and political powers, often not belonging to the village's community. They are involved in development of residential, commercial and industrial premises. They fill in the gap created by laxity of government in term of formal control (Salem, 2015).

\section{Case Study Areas}

The selected cases for this study are peri-urban settlements in Ibeju-Lekki and Ikorodu(Figure 1). Both cases are located outside Lagos metropolitan region. The different dynamics of urbanism in terms of trend of development, drivers of development, demographic composition, infrastructural development and locational potentials, are the motivating factors for choice of the case studies. Also, Ibeju-Lekki represents the least urbanized peri-urban in Lagos in term of population growth and housing development while Ikorodu represents the highly urbanized peri-urban in Lagos in term of residential development and population growth. Ibeju-Lekki Local Government Area is approximately 75 kilometres long and about 20 kilometres wide and has a land area of about 646 kilometres square, which equals one quarter of the total land mass of Lagos State. It is situated at approximately latitude 40 15'north latitude 40 17' north and longitude 13015' east and 13020' east. According to the National Population Commission (2006) census, Ibeju-Lekki had a population of 117,481 out of Lagos State's total of 9,113,605. Ikorodu is located in the North East of Lagos State along the Lagos lagoon and situated at a distance of approximately $36 \mathrm{~km}$ north of Lagos. It occupies a land area of about 345 kilometres square. It is situated at approximately latitude $636^{\prime}$ North and longitude 3 30' East. Ikorodu had an enumerated population of 535,619. The sample frame constitutes the existing buildings in the peri-urban.

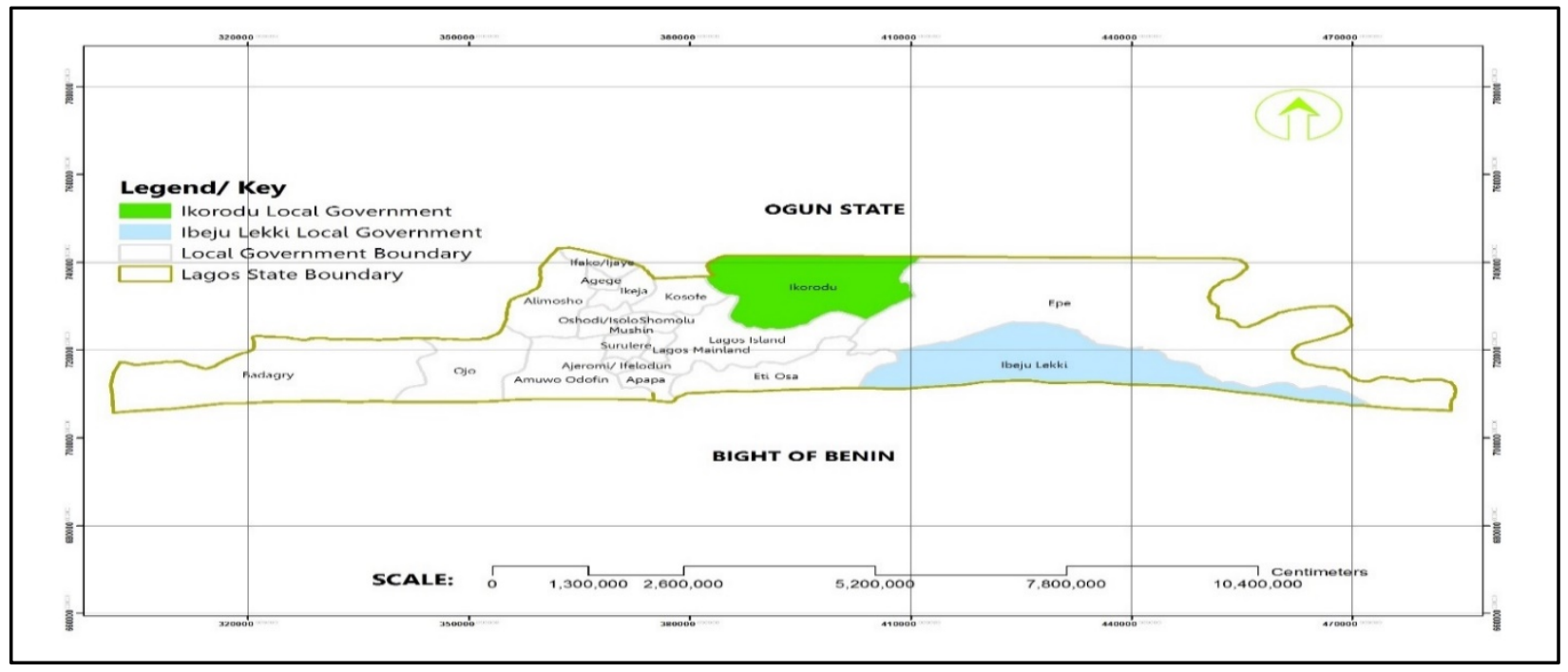

Figure 1. Map of Lagos State showing the case studies

Source: Field work (2017). 


\section{Methodology}

The data for this objective are qualitative and quantitative in nature. The data for this objective were extracted from the responses in the questionnaire instrument, the analysis of observation chart and the analysis of the spatial data. The quantitative data include the socio-demographic profile, drivers of expansion, sources of migration and average commuting time. Data analysis was carried out by subjecting responses from field survey to descriptive statistics. Spatial data like satellite images of different years were acquired from Google Earth while shape-files of the study areas were collected from the Ministry of Physical Planning and Urban Development (MPP\&UD) respectively. The sets of land use maps available for this study spanned from pre1980 to 2002. The maps were in analogue format. They were scanned as images so as to have them in digital format. This process is known as spatial data conversion from analogue to digital. This is significant owing to the series of required spatial operation that will be performed later. These sets of maps initially converted into digital format were further brought into ArcGIS environment in order to reference them geographically. This is achieved through assigning datum to the maps appropriately. This process of assigning datum or pairs of coordinates on a map or an image is termed geo-referencing. The datum assigned to these sets of maps reads WGS_84_Zone 31. The geo- referencing was made possible with the shape-files of Lagos State boundary. Both land use maps and satellite images of Ikorodu and Ibeju Lekki were converted from raster (image) format into vector (shape) format. This operation was carried out in order to calculate or find out what had been allocated for different land uses over the period of studies.

\section{Results and Discussion}

5.1 Analysis of Causes of Spatial Expansion in the Study Area

Table1. Land use Analysis in the study area from 1980 -2002 (Pre -2006)

\begin{tabular}{|c|c|c|c|c|c|}
\hline & \multirow[b]{2}{*}{ Land use } & \multicolumn{3}{|c|}{ Ibeju-Lekki } & \multirow[b]{2}{*}{2002} \\
\hline & & Pre 1980 & $1980-2000$ & 2000 & \\
\hline 1 & Agricultural & $54,774.96$ & $20,804.16$ & $46,109.26$ & \\
\hline 2 & Civic, commercial, business & & $1,096.22$ & & \\
\hline 3 & Conservation, water catchment, marshlands & & $6,648.45$ & & \\
\hline 4 & Fishing port & & 195.8 & & \\
\hline 5 & Forest and wild palm trees & & & & $40,536.70$ \\
\hline 6 & Industrial & & & $1,090.05$ & 442.28 \\
\hline 7 & Institutional & & $2,249.78$ & $1,383.80$ & $1,024.21$ \\
\hline 8 & New ocean terminal & & $14,273.05$ & & \\
\hline 9 & Parks, open space, recreation and tourism & & $5,167.74$ & & $2,529.58$ \\
\hline 10 & Residential & & $4,049.27$ & $6,932.13$ & $11,243.00$ \\
\hline \multirow[t]{2}{*}{11} & Water body & $1,830.06$ & $2,120.56$ & $1,089.78$ & 829.25 \\
\hline & Total & $56,605.02$ & $56,605.02$ & $56,605.02$ & $56,605.02$ \\
\hline
\end{tabular}

Source: Lagos State Ministry of Lands (2005). 
Table 2. Land use Analysis in the study area from 1980 -2002 (Pre -2006)

\begin{tabular}{lllccc}
\hline & & \multicolumn{3}{c}{ Ikorodu } \\
\cline { 3 - 5 } & Land use & Pre 1980 & $\mathbf{1 9 8 0 - 2 0 0 0}$ & $\mathbf{2 0 0 0}$ & $\mathbf{2 0 0 2}$ \\
\hline 1. & Agricultural & & $18,236.94$ & $17,268.72$ & $21,084.94$ \\
2. & Civic, commercial, business & & & \\
3. & Conservation, water catchment, marshlands & $4,667.00$ & $7,095.62$ & & \\
4. & Fishing port & & & \\
5. & Forest and wild palm trees & $27,474.05$ & & $2,362.39$ & $4,873.78$ \\
6. & Industrial & & $1,836.35$ & $3,266.90$ & $1,865.31$ \\
7. & Institutional & 274.36 & 974.72 & $1,553.07$ & $1,146.76$ \\
8. & Parks, open space, recreation and tourism & 419.22 & & & \\
9 & Residential & 622.23 & $8,799.78$ & $12,492.33$ & $7,972.62$ \\
10. & Water body & $3,486.56$ & & & \\
& Total & $36,943.41$ & $36,943.41$ & $36,943.41$ & $36,943.41$ \\
\hline
\end{tabular}

Source: Lagos State Ministry of Lands (2005)

\subsection{Settlement Development Patterns in the Study Area from 1980-2016}

Gradual metropolitanisation began in the case studies after 1980 even though there was a noticeable trace of residential development in Ikorodu. Prior year 1980, peri-urban areas in Ibeju-Lekki (Figure 2a) and Ikorodu (Figure 3a) were green areas mostly committed to agriculture, conservation, water catchment, forest and wild palm trees. However, between year 1980 and 2000(Tables 2 \&3), the study areas show a change in land use, residential development expanded both in Ikorodu and Ibeju-Lekki as seen in (Figure 2b\&3b). A gradual push into the peri-urban settlements by the saturation of core metropolitan Lagos due to rapid population growth and as a result of rural-urban drift led to residential development in all Lagos peri-urban settlements from year 1980. With reference to Table 2, residential land use in Ibeju-Lekki increased from 4049.27 hectares of land in 1980 to a higher hectares of 6,932.13 in the year 2000 and it became 11,243.00 hectares in year 2002(Figure 2d). Ikorodu peri-urban, according to the land use analysis (Table 3) shows a higher density of land conversion. Contrary to Ibeju-Lekki having no residential development in years prior to 1980, Ikorodu had 622.23 hectares of residential development. Further residential development in Ikorodu grew from 8,799.78 hectares in 1980 to $12,492.33$ hectares in 2000(Figure 3b) and subsequently to 7,972.62 hectares in year 2002(Figure 3d). The growth pattern in Ibeju-Lekki is motivated by the development of the highways. Awoyaya and Abijo were the pioneering towns because of their closeness to the neighbouring metropolitan centre. However, land speculation aided the growth of the inner rural areas. As shown in the land use map in (Figure 2b), settlements were only along the highway prior year 2000. There was limited infrastructure until government acquisition of land brought about land reclassification in the early 2000s. The growth of the inner periphery was as a result of saturation of built up areas close to the ring roads and cities. The field observation and household interview showed various settlement typologies driven by various reasons from political, topography to socio-cultural. Each settlement typologies was shaped by residential and cultural segregation, also driven by the socio-economic attributes of the residents.

\subsection{Analysis of Residential Land Use in the Study Area between 2006 and 2016}

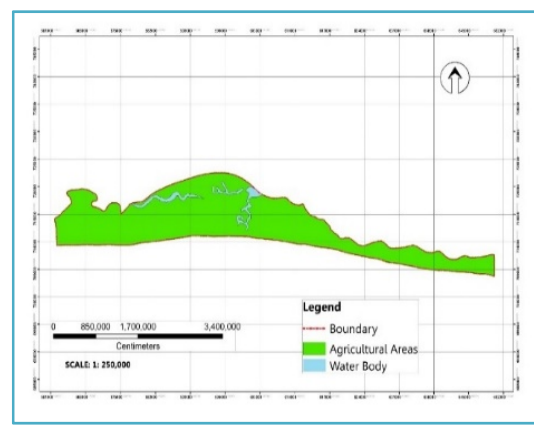

Figure 2a. Pre-1980

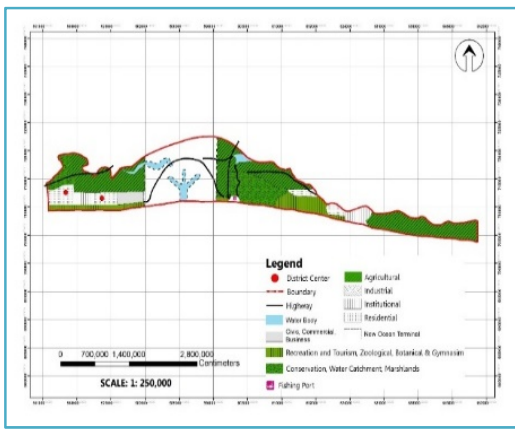

Figure 2b. 1980-2000

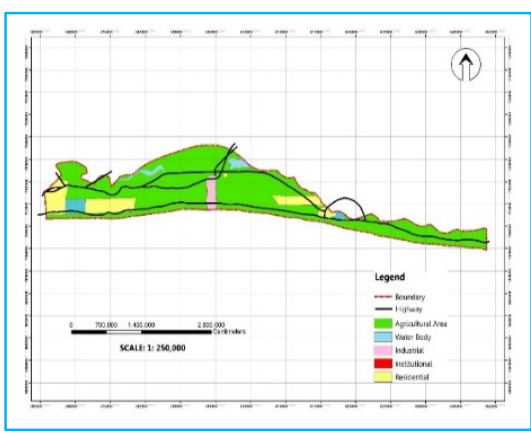

Figure 2c. 2000

[Development trend in Ibeju-Lekki study area Pre-1980, 1980-2000, 2000]

Source: Field work (2017). 


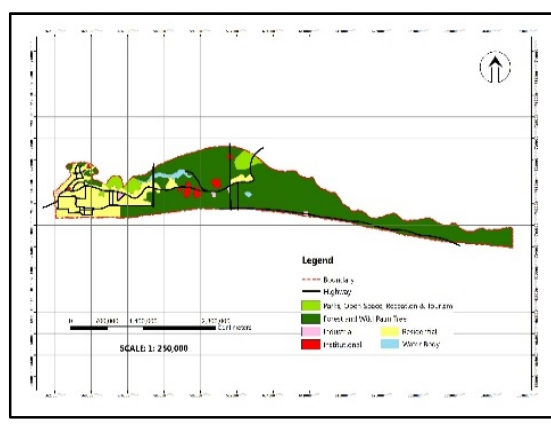

Figure 2d. 2002

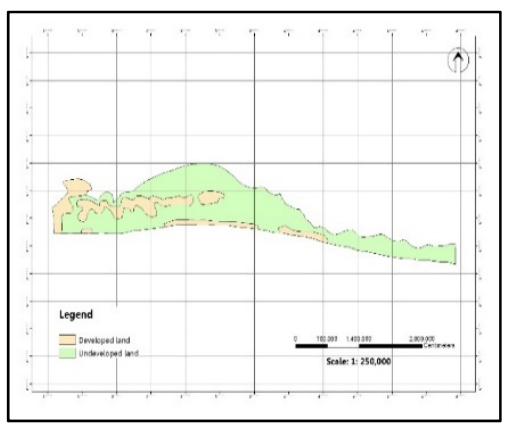

Figure 2e. 2006

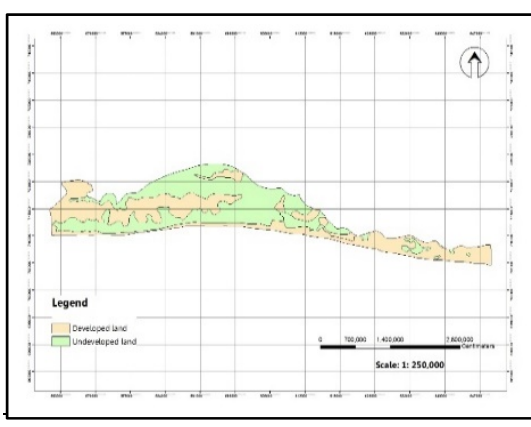

Figure2f. 2016

[Development trend in Ibeju-Lekki study area 2002, 2005, 2016]

Source: Field work (2017).

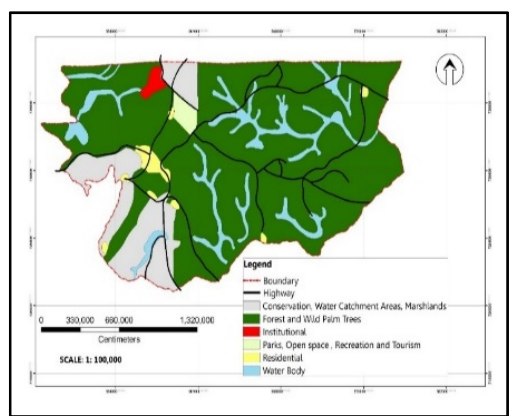

Figure 3a. Pre-1980

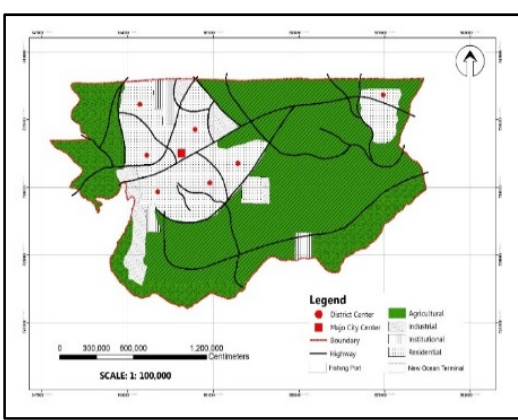

Figure 3b. 1980-2000

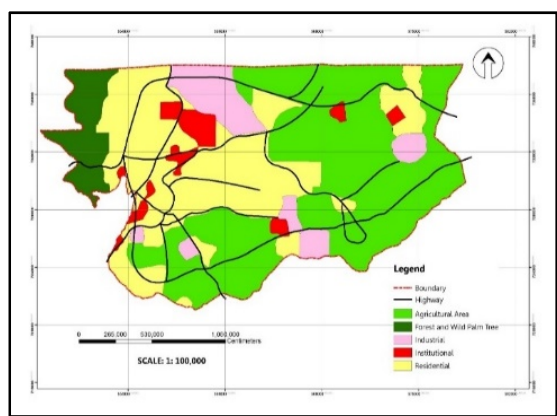

Figure 3c. 2000

[Development trend in Ikorodu study area Pre-1980, 1980-2000, 2000]

Source: Field work (2017).

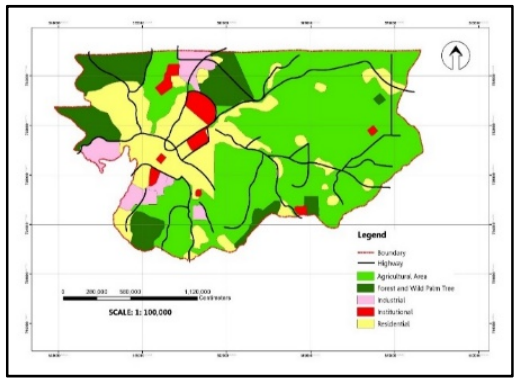

Figure 3d. 2002

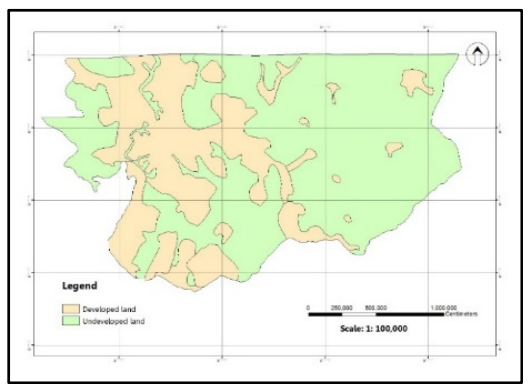

Figure 3e. 2006

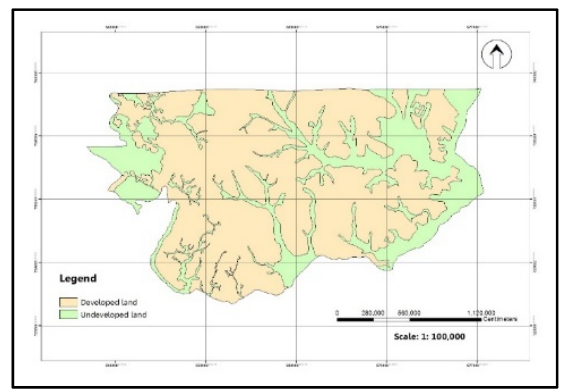

Figure 3f. 2016

[Development trend in Ikorodu study area 2002, 2006, 2016]

Source: Field work (2017).

It can be observed in (Figures 2e, 2f) and (Figures 3e and 3f) that both Ibeju-Lekki and Ikorodu have experienced noticeable growth in housing development between year 2006 and 2016. However, the degree of spatial expansion differs. Ikorodu could be seen to have developed more in areal extent than Ibeju-Lekki. While a greater percentage of Ibeju-Lekki is still undeveloped, Ikorodu have less undeveloped area of land mass having experienced a surge in housing development within the study timeline. Housing development in both locations is motivated by different factors. Analysis of the factors influencing residential development in each of the case study is therefore presented further in the study. 
Table 3. Factor Analysis on Factors influencing migration to the study areas

\begin{tabular}{lllllll}
\hline & \multicolumn{3}{c}{ Ibeju-Lekki } & \multicolumn{3}{c}{ Ikorodu } \\
\cline { 2 - 7 } Drivers of expansion & \multicolumn{3}{c}{ Components } & \multicolumn{3}{c}{ Components } \\
\cline { 2 - 8 } & 1 & 2 & 3 & 1 & 2 \\
\hline Land affordability & 0.33 & 0.403 & -0.185 & -0.85 & 0.228 & -0.201 \\
Low cost of living & -0.15 & -0.033 & -0.488 & 0.59 & 0.208 & -0.038 \\
Closeness to place of work & -0.04 & 0.712 & 0.369 & -0.06 & 0.337 & 0.358 \\
Quality Environment & 0.574 & 0.051 & -0.156 & 0.40 & 0.465 & -0.212 \\
Employment & 0.014 & -0.726 & 0.261 & 0.15 & -0.007 & 0.66 \\
Education(Study) & 0.007 & -0.04 & 0.053 & -0.03 & -0.191 & -0.025 \\
Good and accessible road network & 0.735 & 0.151 & 0.211 & -0.02 & -0.173 & -0.023 \\
Less cost of transportation & 0.326 & 0.131 & 0.422 & 0.06 & 0.259 & 0.45 \\
Land security & 0.676 & 0.093 & 0.061 & -0.02 & -0.155 & -0.02 \\
Property investment & 0.532 & -0.174 & 0.008 & 0.1 & -0.621 & -0.124 \\
Cooperative/government land acquisition & -0.1 & 0.003 & -0.005 & 0.02 & -0.06 & -0.24 \\
Source of Inheritance & 0.3 & 0.059 & -0.528 & 0.19 & 0.374 & -0.477 \\
Closeness Tribesmen & -0.06 & -0.079 & 0.479 & -0.01 & -0.35 & -0.051 \\
\hline
\end{tabular}

Ibeju-Lekki: Extraction Method: Principal Component Analysis.

Rotation Method: Varimax with Kaiser Normalization.

a. Rotation converged in 4 iterations.

Ikorodu: Extraction Method: Principal Component Analysis.

Rotation Method: Varimax with Kaiser Normalization.

a. Rotation converged in 7 iterations.

\subsection{Factors Influencing Respondents' Migration to the Case Studies}

Further data compaction using data analysis (Table 3) was carried out on the factors influencing migration to both Ibeju-Lekki and Ikorodu peri-urban settlements to determine the major drivers of expansion. The factors that loaded adequately in Ibeju-Lekki are affordable land for housing and commercial development, closeness to place of work, better environment for living, easy access to road network and public transportation, less cost of transportation, access to secured land tenure, property investment and closeness to tribesmen. Ibeju-Lekki peri-urban is the home of high quality exclusive gated housing developments facilitated by the private developers. This factor motivated the residential mobility by the high middle income and high income group in quest for a good neighbourhood and quality housing. These factors are then categorized based on their relationships to be the factors driving housing development in Ibeju-Lekki peri-urban settlements:

\subsubsection{Loading Categories (Ibeju-Lekki)}

Availability and Affordability of conflict-free land tenure: Related factors loading under this factor are access to secure land tenure and land affordability. In comparison to the urban core, individuals have access to affordable lands for housing and economic-related developments in the peri-urban and this is a major pull factor for peri-urbanisation.

Proximity and good transportation links: Related factors in the analysis are closeness to work, closeness to tribesmen, good and accessible road network. Combined transportation related factors loaded most in the factor analysis. Most peri-urban residents work in the city centre while having residential location in the metropolitan fringe. Availability of good transportation network is a motivation for living in the suburb.

Environmental Quality: This constitutes the major reason for housing development for residents in gated exclusive residential developments especially the high middle income and the high income group. 

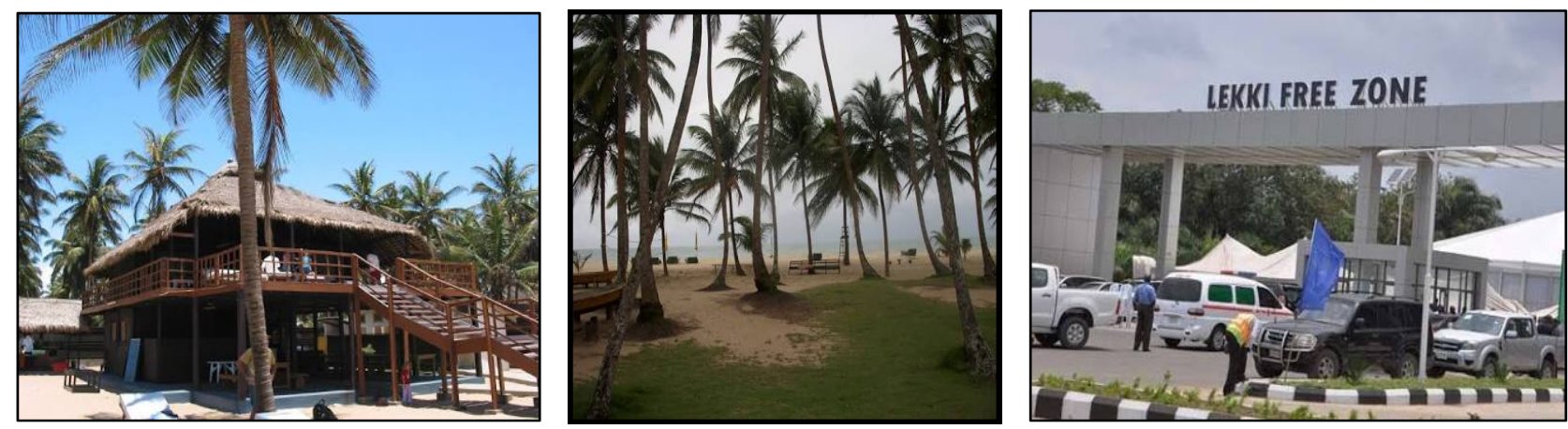

Figure 4. Tourism and socio-economic ventures in Ibeju-Lekki peri-urban settlements

\subsubsection{Loading Categories (Ikorodu)}

Further data analysis using factor analysis (Table 3) shows that different factors loaded adequately and differently from what was experienced with Ibeju-Lekki. The major factors in Ikorodu are low cost of living, employment, closeness to place of work, environmental quality, low cost of transportation and source of inheritance. Some of the institutions providing employment are shown in Figure 5. These factors could further be categorised into three major factors:

Socio-economic benefits: Related factors loading under this factor are low cost of living, employment opportunities and Source of inheritance.

Proximity and good transportation links: Related factors in the analysis are closeness to work and minimal cost of transportation.

Better environment for living: This constitutes the major reason for housing development for residents of government-led and private developer-led housing developments in the study area.
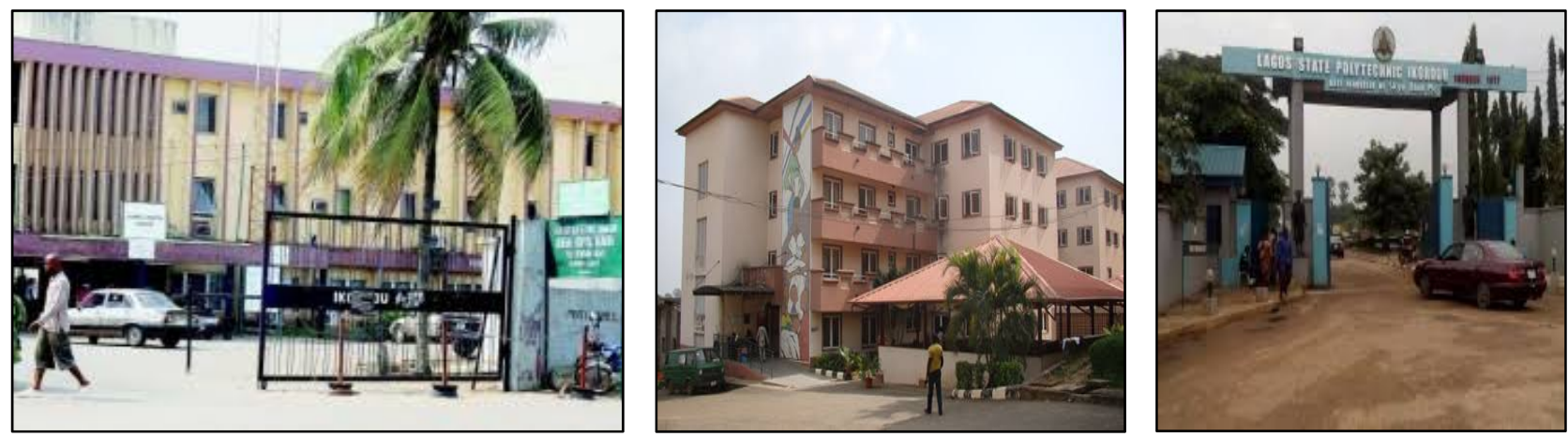

Figure 5. Different government and academic institutions in Ikorodu Peri-urban settlements

Source: Field survey(2017).

Table 4. Housing population in the study area between years 1991- 2016

\begin{tabular}{lll}
\hline & Ibeju-Lekki & Ikorodu \\
\hline Year & Housing Units & Housing Units \\
\hline 1991 & 1,635 & 18,211 \\
2006 & 7,701 & 52,819 \\
2012 & $* * 10,128$ & $* * 89,609$ \\
2016 & $* 11,746$ & $* 33,562$ \\
\hline
\end{tabular}

Source: National population Commission (2006).

*Source: Field survey (2017). ** Source: (LASG Ministry Of Economic Planning and \& Budget, 2013). 


\subsection{Housing Development Trend in the Study Area}

Data from the National Population Commission (2006) census analysed in Table 4 shows a huge leap in housing development in both Ibeju-Lekki and Ikorodu local government areas from the year 1991. In Ibeju-Lekki Local Government, a total of 1,635 units of housing was noted in the 1991 census, a sum of 7,701 in 2006. 10,128 residential units were counted in the year 2012 according to (LASG Ministry of Economic Planning and Budget, 2013). Surface counting of residential developments aided by aerial photographs during the field work in September, 2016 showed a total of 11,746 units of housing in the selected sixteen peri-urban settlements in Ibeju-Lekki. However, Ikorodu Local Government has witnessed a more tremendous housing development than Ibeju-Lekki. Housing development in Ikorodu was 18,211 units in 1991, 52,819 units in 2006, 89,609 units in 2012. A total of 33,562 housing units were captured in 2016 during surface counting of selected eighteen peri-urban settlements in Ikorodu.

\subsubsection{Contributions of Housing Providers to Peri-Urban Expansion in the Study Areas}

Three notable housing providers in the study area are individuals, private developers and the State government. Analysis of field survey presented in Table 5 shows individuals as major contributors of housing in both case studies. Though, the degree of contribution differ. Individuals constitute $84.4 \%$ of development in Ibeju-Lekki while $71.5 \%$ of this group constitute the major housing provider in Ikorodu. Activities of private developers thrive better in Ikorodu than Ibeju-Lekki with $25.6 \%$ of the housing coming from them, a lower contribution by this category of people is seen in Ibeju-Lekki, 14.5\%. Figure 6 shows selected government-led and private developer-led housing in the study area. Finally government contribution to housing development in both study areas was negligible, $1.1 \%$ and $2.6 \%$ respectively. But the differential in the regional government contribution is transferred to better improved infrastructure and hence the reason for wider expansion in Ikorodu peri-urban settlements.

Table 5. Contributions to housing development by housing providers

\begin{tabular}{lllll}
\hline & \multicolumn{2}{c}{ Ibeju-Lekki } & \multicolumn{2}{c}{ Ikorodu } \\
\cline { 2 - 5 } Housing Providers & $\mathrm{N}=366$ & $\%$ & $\mathrm{~N}=379$ & $\%$ \\
\hline Individuals(Self-help housing) & 309 & 84.4 & 271 & 71.5 \\
Private developer/Cooperative & 53 & 14.5 & 98 & 25.6 \\
Government & 4 & 1.1 & 10 & 2.6 \\
\hline
\end{tabular}

Source: Field survey (2017).
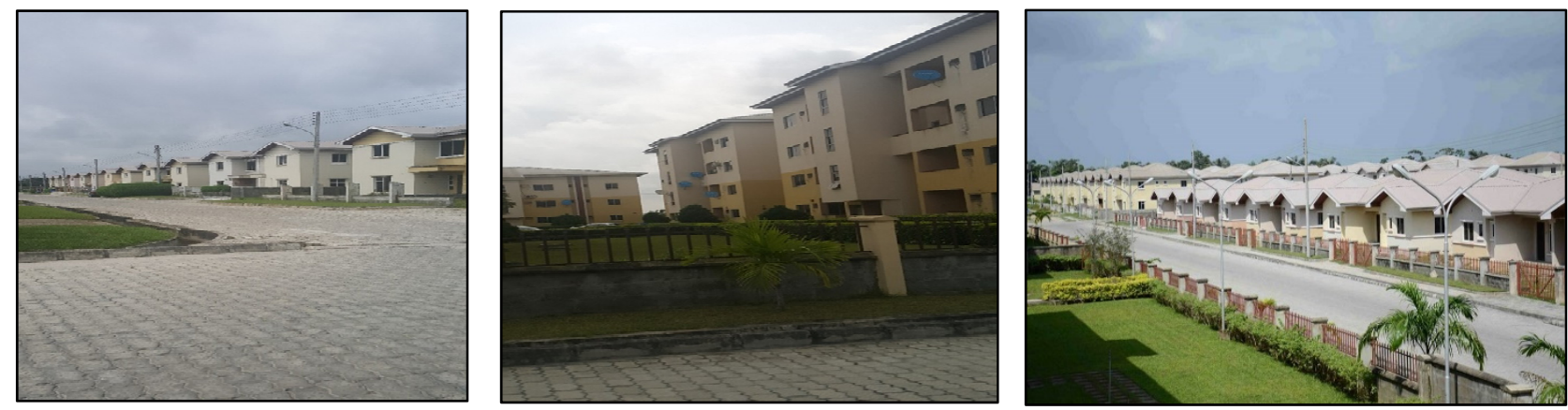

Figure 6. Exclusive gated government-led housing and private developer-led housing scheme in Ibeju-Lekki peri-urban

\subsection{Impact of Locational Convenience on Spatial Expansion of the Study Area}

The variables to be considered for locational convenience in this study are closeness to work, closeness to market/CBD and availability of public transport and the impact of this variable on the differential in the peri-urbanisation of the two case studies is presented in Table 6.

\subsubsection{Closeness to Work}

A greater percentage of the respondents in Ibeju-Lekki has good locational proximity to their places of work as 
indicated by the analysis in Table 6 . While $85.8 \%$ have good proximity to work, about $14.2 \%$ are affected by their residential location in relation to proximity to work. In Ikorodu, the good distribution of government organisations and strategic locations of most institutions close to both primary and secondary roads makes it easier for peri-urban residents to access their works. A fair percentage of $72.8 \%$ of the respondents' population claimed to have good proximity to their works while $26.9 \%$ were not. This corroborates Alonso's access trade off model that says that there is an opportunity lost and opportunity cost in choosing a residential location in peri-urban settlements. While the cost of land may be cheaper in the peri-urban, there is a trade off in commuting time, especially in places farther away from the city centre.

\subsubsection{Closeness to the Central Business District}

Locational proximity to the central business district is an advantage in the peri-urban. $86.1 \%$ of household heads in Ibeju-Lekki were seen to be close to the Central Business District in the peri-urban while $13.9 \%$ are not close to the Central Business District thus increasing their frequency of visit to the city centres for basic needs. A reasonable size of the respondents in Ikorodu, $72.0 \%$ was favoured by the closeness of their residential locations to the central business districts, $27.4 \%$ were not close to the CBD and $0.5 \%$ represents missing systems in the questionnaires.

\subsubsection{Availability of Public Transport}

About 22. $1 \%$ of household heads in Ibeju-Lekki see the lack of public transport as a locational deficiency in Ibeju-Lekki peri-urban while $77.6 \%$ are not affected by lack of public transport. Observation through the field work shows a high cost of transportation from one location to another for those without personal vehicles within Ibeju-Lekki peri-urban settlements. There exists a good public transportation system in Ikorodu, provided by both government and individuals as supported by the analysis showing $83.9 \%$ claiming to have access to good transport and $15.6 \%$ showing they have not.

Table 6. Analysis of locational convenience in the case studies

\begin{tabular}{lllll}
\hline \multirow{2}{*}{ Variable } & \multicolumn{2}{l}{ Ibeju-Lekki } & \multicolumn{2}{l}{ Ikorodu } \\
\cline { 2 - 5 } Closeness to work & $\mathrm{N}=366$ & $\%$ & $\mathrm{~N}=379$ & $\%$ \\
Yes & & & & \\
No & 314 & 85.8 & 276 & 72.8 \\
Missing system & 52 & 14.2 & 102 & 26.9 \\
Closeness to CBD & 0 & 0 & 1 & 0.3 \\
Yes & & & & 72 \\
No & 315 & 86.1 & 273 & 27.4 \\
Missing system & 51 & 13.9 & 104 & 0.5 \\
Availability of public transport & 0 & 0 & 2 & \\
Yes & 284 & 77.6 & & 83.9 \\
No & 81 & 22.1 & 318 & 15.6 \\
Missing system & 1 & 0.3 & 59 & 0.5 \\
\hline
\end{tabular}

Source: Field survey (2017).

\subsection{Assessment of Impact of Linkage on Peri-Urbanisation in the Study Areas}

The importance of interconnectivity between the rural areas and the neighbouring urban centres cannot be downplayed in the expansion of peri-urban settlements. Ease of linkage (Figure 7) facilitates good commuting and encourages a pull to the city peripheral both for housing and industrial development. The analysis presented in Table 7 shows the commuting patterns of the respondents in the case studies. Car ownership in Ibeju-Lekki peri-urban is $46.2 \%$ meaning that almost half of the population relies on their personal cars for daily commuting. This could attribute for the less impact of availability of good public transportation on the growth of Ibeju-Lekki peri-urban settlements. $34.2 \%$ of the respondents' population travel to the urban centres daily, $33.3 \%$ commute to 
the city center weekly and $31.4 \%$ travel as the needs arise. $42.6 \%$ of the respondents travel for work related purpose, $30.3 \%$ travel to either the city centre and neighbouring peri-urban for groceries while $27 \%$ travel to the city centre for supply of materials for their enterprises. The highest commuting time to and from places of work daily in Ibeju-Lekki peri-urban is three hours while the least commuting time is thirty minutes. $35.2 \%$ spends an average of sixty minutes (one hour) daily commuting, $24.6 \%$ spend ninety minutes, $15.6 \%$ spends less than 30 minutes, $14.2 \%$ spends almost 180 minutes(three hours) while $10.4 \%$ spend an average of 120 minutes( two hours) commuting daily.

In Ikorodu, a sizable portion of the respondents also have their own automobiles. $42.2 \%$ of the respondents' have vehicles while $56.5 \%$ do not have cars and $1.3 \%$ responses showed neither. $38.8 \%$ of Ikorodu peri-urban residents commute to the city daily, $36.1 \%$ on a weekly basis and others $(25.1 \%$ as the need arises). This analysis shows a high level of linkage to the city from Ikorodu peri-urban. Concerning the pattern of linkage to the city by the peri-urban residents, $54.4 \%$ of the respondents' population commute to the city for work, $23.2 \%$ for groceries, $20.3 \%$ for supply of their medium scale businesses and $0.6 \%$ for other needs. There was six missing system from the questionnaires. The daily average commuting hour shows a missing system of three. $31.1 \%$ of the residents spend less than 30 minutes for daily commuting to work, $30.6 \%$ spend about 1 hour, $13.5 \%$ show a commuting time of 1 hour, thirty minutes, $16.6 \%$ spend between 1 hour to 2 hours, $5.8 \%$ spend 3 hours and other unspecified commuting time is about $1.6 \%$.

Table 7. Impact of linkage on peri-urban expansion in the study areas

\begin{tabular}{|c|c|c|c|c|}
\hline & \multicolumn{2}{|c|}{ Ibeju-Lekki } & \multicolumn{2}{|c|}{ Ikorodu } \\
\hline & $\mathrm{N}=366$ & $\%$ & $\mathrm{~N}=379$ & $\%$ \\
\hline \multicolumn{5}{|l|}{ Car ownership } \\
\hline Yes & 169 & 46.2 & 160 & 42.2 \\
\hline No & 197 & 53.8 & 214 & 56.5 \\
\hline Neither & 0 & 0 & 5 & 1.3 \\
\hline \multicolumn{5}{|c|}{ Average Time of commuting } \\
\hline Daily & 125 & 34.2 & 147 & 38.8 \\
\hline Weekly & 122 & 33.3 & 137 & 36.1 \\
\hline Others(specify) & 115 & 31.4 & 95 & 25.1 \\
\hline Not applicable & 1 & 0.3 & 0 & 0 \\
\hline Missing & 0 & 0 & 0 & 0 \\
\hline \multicolumn{5}{|c|}{ Purpose of commuting(Linkage) } \\
\hline Work & 156 & 42.6 & 206 & 54.4 \\
\hline Groceries & 111 & 30.3 & 88 & 23.2 \\
\hline Supply for business & 99 & 27 & 77 & 20.3 \\
\hline Others & 0 & 0 & 2 & 0.6 \\
\hline Missing & 0 & 0 & 6 & 1.6 \\
\hline \multicolumn{5}{|c|}{ Average daily commuting time } \\
\hline Less than 30 minutes & 57 & 15.6 & 118 & 31.1 \\
\hline $31-60 \operatorname{mins}(1 \mathrm{hr})$ & 129 & 35.2 & 116 & 30.6 \\
\hline 61-90min (1\&half hrs.) & 90 & 24.6 & 51 & 13.5 \\
\hline $91-120 \mathrm{mins}(2 \mathrm{hrs})$ & 38 & 10.4 & 63 & 16.6 \\
\hline $121-180 \mathrm{mins}(3 \mathrm{hrs})$ & 51 & 13.9 & 22 & 5.8 \\
\hline Others & 1 & 0.3 & 6 & 1.6 \\
\hline Missing & 0 & 0 & 3 & 0.8 \\
\hline
\end{tabular}

Source: Field survey (2017). 

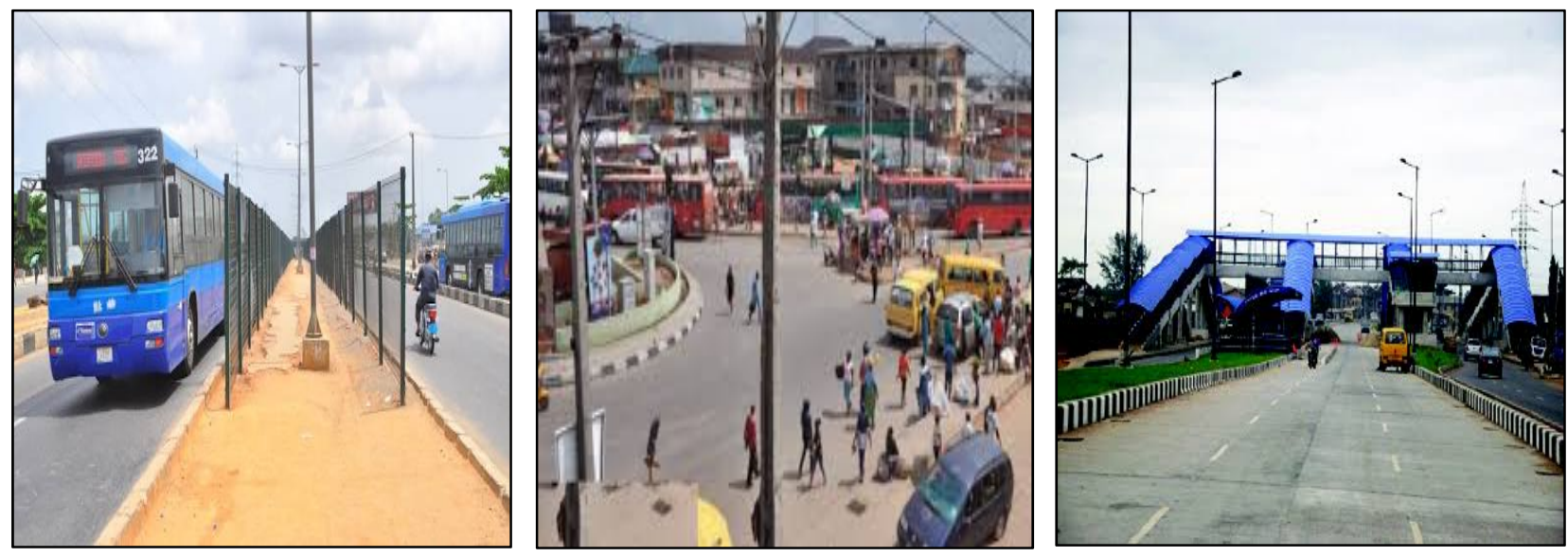

Figure 7. Road linkages in Ikorodu peri-urban

Source: Field survey(2017).

\section{Conclusion}

It is a global phenomenon that spatial areas in the periphery of metropolitan urbanised regions usually experience expansion due to direct impact of population growth and housing challenges in the urban areas. Hence, the surrounding towns become strategic zones for the expansion of urban areas. Prior studies by Binns,Maconachie \& Tanko (2003) and Lawanson, Yadua, \& Salako (2012) have shown that Lagos as a rapidly urbanising region is not exempted from this phenomenon. The major push and pull factors influencing urban-rural residential mobility are land affordability, improved road network and provision of gated exclusive housing developments by private developers in the peri-urban thus creating metropolitanisation of the study areas. The spatial expansion of peri-urban settlements is a direct encroachment into areas originally marked for agricultural land use. Both locations in this study have the direct impact of good locational convenience but Ikorodu has experienced wider expansion due to availability of public transportation. Both locations however have good proximity to the central business District. Commuting trend shows the linkages between the city centre, peri-urban and the rural areas. The peri-urban cannot function in isolation. There are strong dependencies on the urban centres for socio-economic purposes. More respondents commute daily to the city centre for work-related activities in Ikorodu than Ibeju-Lekki. Commuting time from the peri-urban to the city centre for various activities is longer in Ibeju-lekki than Ikorodu. This could attribute for the higher level of development experienced in Ikorodu. Locational benefit is a huge pull factor to the peripheral for residential developments. From this study it can be concluded that the differentials in the trend of peri-urbanisation are traceable to among many factors, the locational convenience, level of the linkages, the residents' socio-demography and the regional government housing policy. The establishment of these factors promote the rapid conversion of rural areas in Lagos metropolitan fringe to peri-urban through transfer of culture by the residents and the corresponding regional development.

\section{Recommendation}

Balanced infrastructure in the peri-urban will curtail the extent of differential in development in Lagos peri-urban. Housing providers should put in consideration the negative effect of poor location on the productivity and degree of satisfaction of residents in peripheral settlements. Infrastructure should be planned to align with housing development. It should not be an afterthought.

\section{References}

Acheampong, R. A., \& Anokye, P. A. (2013). Understanding Households' Residential Location Choice In Kumasi's Peri-Urban Settlements And The Implications For Sustainable Urban Growth. Research On Humanities And Social Sciences, 3(9), 60-70.

Adell, G. (1999). Theories And Models Of The Peri-Urban Interface: A Changing Conceptual Landscape. Development Planning Unit. London: University College London. Retrieved from http://www.ucl.ac.uk/dpu/pui

Allen, A. (2003). Environmental Planning And Management Of The Peri-Urban Interface: Perspectives On An Emerging Field. Journal of Environment and Urbanisation, 15(1), 135-147. 
https://doi.org/10.1177/095624780301500103

Allen, A. (2010). Neither Rural Nor Urban: Service Delivery Options That Work For The Peri-Urban Poor. In Peri-Urban Water And Sanitation Services (pp. 27-61). Netherlands: Springer Netherlands. https://doi.org/10.1007/978-90-481-9425-4_2

Allen, A., Da Silva, N. L., \& Corubolo, E. (1999). Environmental Problems And Opportunities Of The Peri-Urban Interface And Their Impact Upon The Poor. Strategic Environmental Planning And Management For The Peri-Urban Interface Project. London: University College, London. Retrieved from http://discovery.ucl.ac.uk/id/eprint/37

Appiah, D. O., Bugri, J. T., Forkuo, E. K., \& Boateng, P. K. (2014). Determinants Of Peri-Urbanization And Land Use Change Patterns In Peri-Urban Ghana. Journal Of Sustainable Development, 7(6), 96-106. http://dx.doi.org/10.5539/jsd.v7n6p95

Bah, M., Cissé, S., Diyamett, B., Diallo, G., Lerise, F., Okali, D., \& Cecilia, T. (2003). Changing Rural-Urban Linkages In Mali, Nigeria and Tanzania. Environment And Urbanization, 15(1), 1-12. https://doi.org/10.1177/095624780301500104

Binns, J., Maconachie, R., \& Tanko, A. (2003). Water, Land And Health In Urban And Peri-Urban Food Production: The Case Of Kano, Nigeria. KANO Water LDD Revised, 14(5), 431-444. https://doi:10.1002/ldr.571

Browder, J. O., Bohland, J. R., \& Scarpaci, J. L. (1995). Patterns Of Development On The Metropolitan Fringe: Urban Fringe Expansion In Bangkok, Jakarta, And Santiago. Journal Of The American Planning Association, 61(3), 310-327. https://doi/abs/10.1080/01944369508975645.

Dutta, V. (2012). Land Use Dynamics And Peri-Urban Growth Characteristics: Reflections On Master Plan And Urban Suitability From A Sprawling North Indian City. Journal Of Environment And Urbanization ASIA, 3(2), 277-301. https://doi.org/10.1177/0975425312473226

LASG Economic Intelligence Unit. (2012). Meeting Housing Needs In Lagos. Lagos: Lagos State Government.

Lawanson, T., Yadua, O., \& Salako, I. (2012). An Investigation Of Rural-Urban Linkages Of The Lagos Megacity, Nigeria. Journal Of Construction Project Management And Innovation., 2(2), 464-581.

Mcgranaham, G., \& Satterthwaite, D. (2014). Urbanisation Concepts And Trends. London: Institute For International Economics And Development. Retrieved from http://Pubs.Iied.Org/10709IIED

Mcgregor, D., Simon, D., \& Kwasi, N.-G. (2004). The Changing Urban-Rural Interface Of African Cities: Definitional Issues And An Application To Kumasi, Ghana. Journal Of Environment And Urbanization, 16(2), 235-248.

Nwokoro, I. I., \& Dekolo, S. O. (2012). Land Use Change And Environmental Sustainability: The Caseof Lagos Metropolis. In The Sustainable City VII: Urban Regeneration And Sustainability (pp. 157-167). RSA: WIT Press.

Pow, C.-P. (2009). Gated Communities In China: Class, Privilege And The Moral Politics Of The Good City. Oxford UK: Routledge.

Pradoto, W. (2012). Development Patterns And Socioeconomic Transformation In Peri-Urban Area. Berlin: Univerlagtuberlin. http://dx.doi.org/10.14279/depositonce-3276.

Ravetz, J., Fertner, C., \& Nielsen, T. S. (2013). The Dynamics Of Peri-Urbanization. In K. Nilsson, E. Al, \& K. P. Nilsson (Eds.), Peri-Urban Futures: Scenarios And Modals For Land Use Change In Europe (pp. 13-44). Netherland: Springer-Verlag Berlin Heidelberg. http://dx.doi.org/10.1007/978-3-642-30529-0

Rozmi, I., Mohammed, H., \& Rahim, M. N. (2013). Passengers Preferences And Satisfactionof Transport In Malaysia,Part II: A Comparative Of Komuter And LRT Network. Research Journal Of Applied Sciences, Engineering And Technology, 6(8), 1450-1456.

Salem, M. (2015). Peri-Urban Dynamics And Land-Use Planning For The Greater Cairo Region In Egypt. Sustainable Development, 1, 109-119. http://dx.doi.org/10.2495/sd150101.

Satterthwaite, D. (2014). Urbanisation In Low And Middle Income Nations In Africa,Asia,And Latin America. In D. Satterthwaite (Ed.), The Companion To Development Studies (pp. 279). London: Routledge.

Simon, D., Mcgregor, D., \& Nsiah-Gyabaah, K. (2004). The Changing Urban-Rural Interface Of African Cities: Definitional Issues And An Application To Kumasi, Ghana. Journal Of Environment And Urbanization, 
16(2), 235-248. https://doi.org/10.1177/095624780401600214.

Thapa, R. B., \& Murayama, Y. (2010). Drivers Of Urban Growth In The Kathmandu Valley, Nepal: Examining The Efficacy Of The Analytic Hierarchy Process. Applied Geography, 30(1), $70-83$. https://doi.org/10.1016/j.apgeog.2009.10.002.

Wu, F., Zhang, F., \& Webster, C. (2013). Informality And The Development And Demolition Of Urban Villages In The Chinese Peri-Urban Area. Urban Studies, 50(10), $1919-1934$. https://doi.org/10.1177/0042098012466600

\section{Copyrights}

Copyright for this article is retained by the author(s), with first publication rights granted to the journal.

This is an open-access article distributed under the terms and conditions of the Creative Commons Attribution license (http://creativecommons.org/licenses/by/4.0/). 